\title{
An essential role for CCAAT/enhancer binding protein $\beta$ in bleomycin-induced pulmonary fibrosis
}

\author{
B Hu,' MR Ullenbruch,' H Jin,' M Gharaee-Kermani ${ }^{2}$ and SH Phan ${ }^{\prime *}$ \\ 'Department of Pathology, University of Michigan Medical School, Ann Arbor, Michigan, USA \\ ${ }^{2}$ Department of Internal Medicine, University of Michigan Medical School, Ann Arbor, Michigan, USA
}

*Correspondence to: Dr SH Phan, Department of Pathology, University of Michigan Medical School, Ann Arbor, MI 48109-2200, USA.

E-mail:shphan@umich.edu

No conflicts of interest were declared.
Received: 23 August 2006

Revised: 2 November 2006

Accepted: 7 November 2006

\begin{abstract}
Pulmonary fibrosis is characterized by inflammation, genesis of myofibroblasts, and abnormal tissue repair. Despite extensive research, its pathogenesis remains incompletely understood. Previously, the transcription factor CCAAT/enhancer binding protein $\beta$ $(\mathrm{C} / \mathrm{EBP} \beta)$ was found to be a key regulator of myofibroblast differentiation in vitro, and to be involved in the acute phase and inflammatory responses. In an attempt to test the role of $\mathrm{C} / \mathrm{EBP} \beta$ in the development of pulmonary fibrosis, experiments using $C / E B P \beta$ null mice and their wild-type littermates were conducted. Our findings indicated that, compared to wild-type mice, animals deficient in C/EBP $\beta$ showed significantly reduced fibrotic lesions and collagen deposition in the lung upon endotracheal injection of bleomycin. Further studies on the mechanisms by which $\mathrm{C} / \mathrm{EBP} \beta$ regulates fibrosis indicated that knockout of $C / E B P \beta$ attenuates inflammatory cytokine expression in bleomycin-treated mice. The reduced $\alpha$ smooth muscle actin gene expression in either isolated lung fibroblasts or lung tissue from bleomycin or saline-treated $C / E B P \beta$ deficient mice suggests that $C / E B P \beta$ regulates myofibroblast differentiation during fibrosis. Consistent with this finding, cells from C/EBP $\beta$ deficient mice exhibited higher proliferative rates than those from wild-type mice. These data suggest that $C / E B P \beta$ plays an essential role in pulmonary fibrosis and that this role appears to be multifactorial with respect to cytokine expression, cell differentiation, and proliferation. Copyright (c) 2006 Pathological Society of Great Britain and Ireland. Published by John Wiley \& Sons, Ltd.
\end{abstract}

Keywords: C/EBP $\beta$; fibrosis; smooth muscle actin; bleomycin

\section{Introduction}

A key phenomenon considered to be important in the pathogenesis of pulmonary fibrosis is the de novo genesis of the myofibroblast, which presumably arises by differentiation from precursor cells, such as the adventitial fibroblast [1-4]. A common and useful marker for myofibroblast differentiation is the expression of $\alpha$-smooth muscle actin ( $\alpha$-SMA) $[1,2,5,6]$. Hence, insight into the induction of myofibroblast differentiation is afforded by studies of regulation of induction of this gene. A recent study shows that CCAAT/enhancer binding protein $\beta(\mathrm{C} / \mathrm{EBP} \beta)$, a basic leucine zipper transcription factor, is a key regulator of $\alpha$-SMA expression and myofibroblast differentiation in isolated lung fibroblasts, by binding to a $\mathrm{C} / \mathrm{EBP} \beta$ binding element identified in the $\alpha$-SMA promoter [7]. Two major isoforms of $\mathrm{C} / \mathrm{EBP} \beta$ have been described and found to be expressed in certain cells [8-10]. The larger of these isoforms has been designated as liver-enriched activator protein (LAP), while the truncated form is known as liver-enriched inhibitor protein (LIP). The latter contains the DNA binding domain of LAP but lacks its activation domain [8-10]. LAP activates $\alpha-S M A$ gene expression, while LIP inhibits expression by competing for binding to the $\mathrm{C} / \mathrm{EBP} \beta$ binding consensus on the $\alpha$-SMA promoter [7]. Thus the LIP isoform by virtue of its ability to bind DNA but lacking in the activation domain might be construed as behaving in a dominant negative manner. Despite this in vitro evidence of cellular regulation by $\mathrm{C} / \mathrm{EBP} \beta$ isoforms, their in vivo role in the pathogenesis of pulmonary fibrosis, and specifically its role in genesis of the myofibroblast, remains to be determined.

In this paper, the regulatory role of $\mathrm{C} / \mathrm{EBP} \beta$ in the development of pulmonary fibrosis was determined by comparing the responses of $C / E B P \beta$ null mice and wild-type mice with endotracheal bleomycin treatment. The results indicated that, upon endotracheal injection of bleomycin, $\mathrm{C} / \mathrm{EBP} \beta$ deficient mice showed significantly reduced pulmonary fibrosis and collagen deposition compared with their wild-type littermates. Further attempts to identify the mechanism for the attenuated fibrosis in $C / E B P \beta$ null mice indicated that $\mathrm{C} / \mathrm{EBP} \beta$ deficiency attenuated collagen gene transcription and inhibited the genesis of the 
myofibroblast, the major cell that produces collagen lung fibrotic lesions. Furthermore, lung expression of some cytokines was diminished in bleomycin-treated deficient mice relative to that in wild-type controls. In vitro studies of fibroblasts isolated from these mice revealed that $C / E B P \beta$ null fibroblasts grew faster than wild-type fibroblasts despite being deficient in myofibroblast differentiation. Taken together, these data suggest that $\mathrm{C} / \mathrm{EBP} \beta$ play an essential role in the induction of pulmonary fibrosis.

\section{Material and methods}

\section{Animal treatment}

$\mathrm{C} / \mathrm{EBP} \beta$ deficient mice (C57BL/6 background) were bred from breeding pairs, which were generous gifts of Dr PF Johnson (National Cancer Institute, National Institutes of Health, Bethesda, MD) and generated as previously described [7]. Bleomycin-induced pulmonary fibrosis was induced as previously described [11]. The control group received the same volume of sterile phosphate-buffered saline only (saline treated). At 7 or 21 days after bleomycin injection, the mice were sacrificed and the lungs of some of the mice were removed and extracted for total mRNA and total protein, while the remainder was formalin-fixed and stained for routine histopathology. Animal care was in accordance with NIH ethics, procedures, and regulations.

\section{Cell culture}

Lung fibroblasts were isolated as described previously [7]. The cells were cultured and maintained in Dulbecco's modified Eagle's medium (DMEM) supplemented with $10 \%$ plasma-derived serum (Cocalico Biologicals, Reamstown, PA, USA), 100 U/ml penicillin, $100 \mathrm{U} / \mathrm{ml}$ streptomycin, $0.25 \mathrm{U} / \mathrm{ml}$ Fungizone, $1 \%$ insulin/transferrin/selenium (Sigma-Aldrich, St Louis, MO, USA), $5 \mathrm{ng} / \mathrm{ml}$ platelet-derived growth factor (R\&D Systems, Minneapolis, MN, USA), and $10 \mathrm{ng} / \mathrm{ml}$ EGF (R\&D Systems). Cells were used between passages 3 to 5 .

\section{Morphological analysis}

Morphological analysis was performed on formalinfixed, paraffin-embedded lung tissue sections and stained with haematoxylin and eosin (H\&E), as previously described [12].

\section{Hydroxyproline assay}

As a measure of fibrosis, total lung hydroxyproline content was determined by colorimetric assay after acid hydrolysis, as described previously [13].

\section{Western blotting}

Extracts of lung tissue homogenates or fibroblast lysates were prepared and analysed for the indicated proteins by western blotting as before [7]. The anti- $\alpha$ SMA and anti-procollagen I antibodies were from Sigma (St Louis, MO, USA). Equal loading was confirmed by blotting the membrane with anti- $\beta$ tubulin antibody (Santa Cruz Biotechnology, Santa Cruz, CA, USA).

\section{mRNA analysis}

Determination of mRNA for the indicated genes was undertaken using real time polymerase chain reaction (PCR) as before [11]. With this method, a CT value reflects the cycle number at which DNA amplification is detected. The amount of target, normalized to endogenous reference and relative to a calibrator, is given by $2^{-\Delta \Delta C T}$ [14]. Total RNA was extracted from either murine lung tissue or fibroblasts as indicated. For each assay, $200 \mathrm{ng}$ of total RNA was used as template and glyceraldehyde-3-phosphate dehydrogenase (GAPDH) mRNA was used as internal control to normalize the amount of input RNA. One-step real time reverse transcriptase (RT)-PCR $\left(48^{\circ} \mathrm{C}\right.$ for $30 \mathrm{~min}, 95^{\circ} \mathrm{C}$ for $10 \mathrm{~s}$, followed by 50 cycles of $95^{\circ} \mathrm{C}$ for $10 \mathrm{~s}, 60^{\circ} \mathrm{C}$ for $1 \mathrm{~min}$ ) was undertaken with Taqman One Step RT-PCR Master Mix (Applied Biosystems, Foster City, CA, USA) using a GeneAmp 5700 Sequence Detection System (PE/ABI). Predeveloped primers and probes for transforming growth factor $\beta 1$ (TGF $\beta 1$ ), interleukin (IL)- $1 \beta$, tumour necrosis factor $\alpha$ (TNF $\alpha)$, monocyte chemotactic peptide 1 (MCP1), and GAPDH were purchased from Applied Biosystems (PE/ABI, Foster City, CA, USA). Primers and MGB probes (6-FAM conjugated) for $\alpha$-SMA, procollagen I and $\mathrm{C} / \mathrm{EBP} \beta$ were designed with software Primer Express 2.0 (Applied Biosystems) and synthesized by Applied Biosystems. The primer sequences were as follows: mouse $\alpha$-SMA: forward primer, $5^{\prime}$ TCCCTGGAGAAGAGCTACGAACT-3'; reverse primer, 5'-AAGCGTTCGTTTCCAATGGT-3'; and probe, 6-FAMCTGACGGGCAGGTGAMGBNFQ; mouse procollagen type I, alpha II: forward primer, 5'-CAACCGTGCTTCTCAGAACATC-3', reverse primer, 5'-TGCCCGTCTCCTCATCCA-3'; and probe, 6-FAMACCACTACTGCAAGAACMGBNFQ; mouse $\mathrm{C} / \mathrm{EBP} \beta$ : forward primer, 5'-AAGCTGAGCGACGA GTACAAGAT-3'; reverse primer, 5'-TGTGCTGCGT CTCCAGGTT-3'; and probe, 6-FAMCGCAACAAC ATCGMGBNFQ.

\section{Fibroblast proliferation assay}

Mouse lung fibroblasts isolated from either bleomycintreated $C / E B P \beta^{-/-}$or $C / E B P \beta^{+/+}$mice were seeded $\left(2 \times 10^{4}\right.$ cells/well $)$ in six-well dishes in complete DMEM medium as described above, and were allowed to adhere for $24 \mathrm{~h}$. The cells were then washed and cultured in fresh media supplemented with $10 \%$ plasma-derived serum and growth factors as indicated above. At the indicated time points, the cells were briefly trypsinized for cell counting using a Cell and 
Particle Counter (Beckman Coulter, Inc, Fullerton, CA, USA). Cell proliferation was also determined by $\left[{ }^{3} \mathrm{H}\right]$ thymidine incorporation using a similar protocol; however, the media were supplemented with $1 \mu \mathrm{Ci} / \mathrm{ml}$ $\left[{ }^{3} \mathrm{H}\right]$ thymidine (GE Healthcare Bio-Sciences Corp Piscataway, NJ, USA). At the indicated times the cells were washed twice with cold 5\% trichloroacetic acid and then solubilized with $0.2 \mathrm{~N} \mathrm{NaOH}, 1 \%$ sodium dodecyl sulphate for determination of radioactivity using a scintillation counter. The results were shown as mean \pm SE from three independent experiments.

\section{Statistical analysis}

Statistical analysis was undertaken as before using analysis of variance, followed, where appropriate, by post hoc testing using Scheffés test [7]. A value of $p<$ 0.05 was used as a criterion for statistical significance in comparisons between any two groups.

\section{Results}

\section{Induction of $\mathrm{C} / \mathrm{EBP} \beta$ in bleomycin-induced fibrosis}

Expression of $\alpha$-SMA during myofibroblast differentiation is stimulated by LAP but inhibited by LIP, and the ratio of LAP to LIP is critical in determining cellular differentiation in lung fibroblasts [7]. However, it is not known whether $\mathrm{C} / \mathrm{EBP} \beta$ actually plays a significant role in the development of pulmonary fibrosis. To examine this question initially, we used the bleomycininduced model of pulmonary fibrosis in C57BL/6 mice to look for alterations in lung $C / E B P \beta$ gene expression 7 days after induction of lung injury. Analysis of lung RNA by real time PCR showed a significant increase in $\mathrm{C} / \mathrm{EBP} \beta$ mRNA in lungs of mice treated with bleomycin relative to that in control saline-treated mice (Figure 1). This increase in $C / E B P \beta$ gene expression in bleomycin-treated murine lungs suggests a potential in vivo role for this transcription factor in the pathogenesis of pulmonary fibrosis.

\section{Effects of C/EBP $\beta$ deficiency on lung histopathology}

To further confirm such a role for this factor, mice deficient in $\mathrm{C} / \mathrm{EBP} \beta$ and their wild-type littermates were injected into the endotrachea with bleomycin and analysed for development of fibrosis 21 days later. $C / E B P \beta$ null mice have no detectable phenotype with reference to lung morphology and appear to develop normally, although female null mice have defective ovarian development and thus are infertile [15]. Routine H\&E staining confirmed no detectable histopathological abnormality in lungs of control saline-treated $C / E B P \beta$ null mice, which were indistinguishable from the lungs of wild-type mice (Figure 2). When treated with bleomycin, the wild-type mice showed

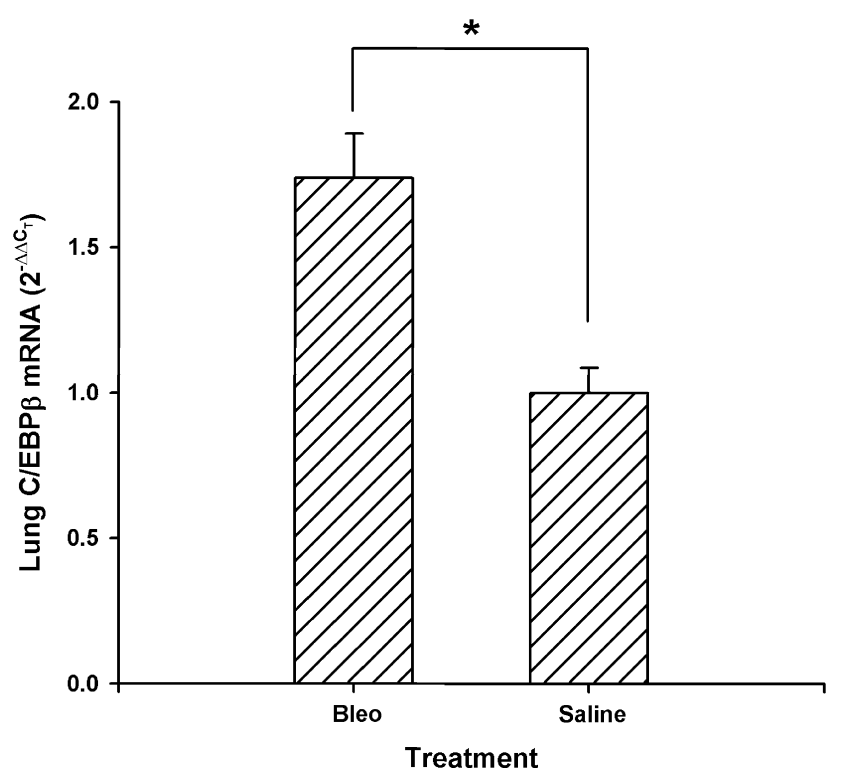

Figure I. Bleomycin treatment induced C/EBP $\beta$ gene expression. Total RNA extracted from lungs of either bleomycin- ('Bleo') or saline- ('Saline') treated C57BL/6 mice $(n=5)$ was analysed for C/EBP $\beta$ mRNA by real time PCR. The results were expressed as $2^{-\Delta \Delta C T}$, with GAPDH mRNA as the endogenous control and the values from the saline-treated controls used as reference. Data are shown as mean \pm SE with $n=5$. The difference between bleomycin-treated and saline-treated lungs was statistically significant $(p<0.05)$

the expected extensive dense lung fibrosis characterized by increased interstitial wall thickness, inflammatory cell infiltration, increased number of fibroblasts, and interstitial collagen deposition. In contrast, although fibrotic lesions were observed, the fibrotic changes were markedly decreased in extent and severity for $C / E B P \beta$ null mice with the same treatment. The fibrotic lesions were less widespread and more narrowly confined to central peribronchial and perivascular areas. Cellularity was much decreased compared to wild-type lungs. Thus the histopathology suggested that $\mathrm{C} / \mathrm{EBP} \beta$ deficiency was associated with a reduction in bleomycin induced pulmonary fibrosis.

\section{Effects on lung collagen}

To confirm and quantify the histological changes observed, lung collagen deposition was determined by the hydroxyproline assay. Whole lung hydroxyproline content was determined at the same time point, namely 21 days after saline or bleomycin injection. Figure 3 shows that bleomycin treatment caused a $60 \%$ increase (over saline-treated controls) in the lung hydroxyproline content of wild-type mice, which was significantly reduced to a $35 \%$ increase in $\mathrm{C} / \mathrm{EBP} \beta$ deficient mice. This $>40 \%$ reduction in fibrosis as measured biochemically was consistent with the histopathology shown in Figure 1.

To further confirm the effect of $\mathrm{C} / \mathrm{EBP} \beta$ on collagen deposition, lung homogenate protein extracts from bleomycin or saline-treated $C / E B P \beta$ null mice 

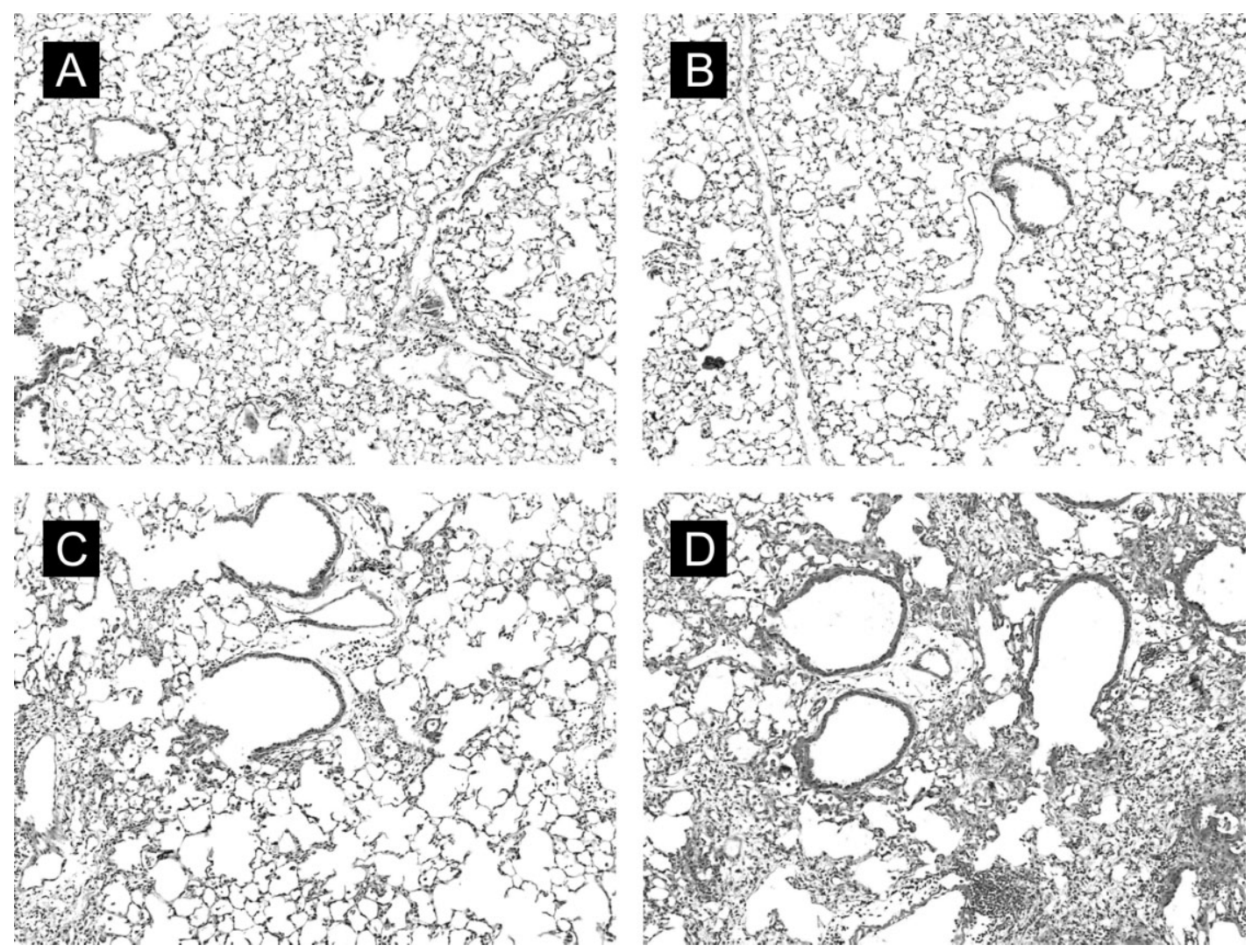

Figure 2. Reduced fibrosis in C/EBP $\beta$ null mice. Representative H\&E stained lung tissue sections from saline- or bleomycin-treated wild-type and C/EBP $\beta$ null mice are shown. (A) C/EBP $\beta$ null, saline-treated; (B) wild-type, saline-treated; (C) C/EBP $\beta$ null, bleomycin-treated; (D) wild-type, bleomycin-treated. All were photographed at $\times 40$ magnification

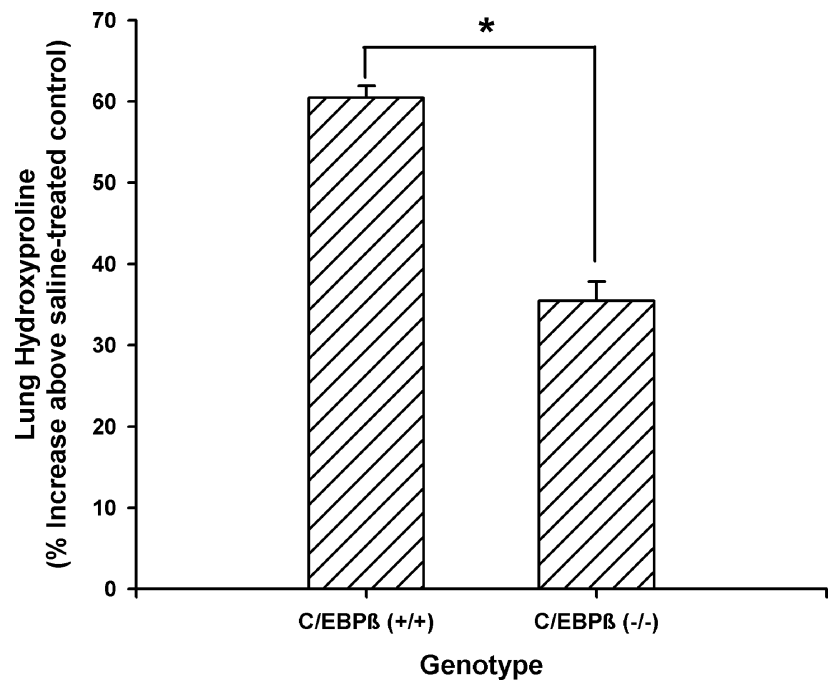

Figure 3. Effects of bleomycin treatment on lung hydroxyproline. Whole lung homogenates from the indicated strain of mice treated with saline or bleomycin were acid hydrolysed and analysed for hydroxyproline content as described in 'Material and methods'. The results were expressed as a percentage of the respective saline control values. Mean \pm SE $(n=5)$ values are shown, and the difference between the two strains of mice was statistically significant $(p<0.05)$

and their wild-type littermates were analysed by western blotting for determination of type I collagen content. The results showed that lung type I collagen content was reduced in control saline-treated
$\mathrm{C} / \mathrm{EBP} \beta$ deficient mice relative to that in wild-type mice. Bleomycin treatment caused an increase in lung type I collagen content in wild-type mice, which was blunted in $\mathrm{C} / \mathrm{EBP} \beta$ deficient mice to an extent that showed only minimal stimulation over the control saline-treated deficient mice. This reduction in basal and bleomycin-induced lung collagen I protein content was accompanied by significant reduction in lung $\alpha 1$ (I) procollagen mRNA (Figures 4 and 5). A $>50 \%$ reduction in basal mRNA levels was observed in the lungs of $\mathrm{C} / \mathrm{EBP} \beta$ deficient mice relative to wild-type mice. Moreover, while bleomycin caused a $>2.5$-fold increase in mRNA in wild-type mice, less than a 0.5 fold (or 50\% increase) was noted for the mutant mice. Thus the biochemical evidence provided further support for deficiency in bleomycin-induced pulmonary fibrosis in $C / E B P \beta$ null mice.

\begin{tabular}{|r|c|c|c|c|}
\hline GENOTYPE: & \multicolumn{2}{|c|}{ C/EBP $\beta^{\text {t+ }}$} & \multicolumn{2}{c|}{ C/EBP $\beta^{\prime-}$} \\
\hline TREATMENT: & Saline & Bleomycin & Saline & Bleomycin \\
\hline Collagen I & & & -1 & $\mathbf{-}--$ \\
\hline$\beta$-tubulin & $--\infty$ & $--\infty$ & $--\infty$ & --- \\
\hline
\end{tabular}

Figure 4. Effects of bleomycin or saline treatment on lung type I collagen. Lung collagen I in homogenates from the indicated groups of mice was analysed by western blotting. $\beta$-Tublin was also detected using anti- $\beta$-tublin antibody as a loading control 


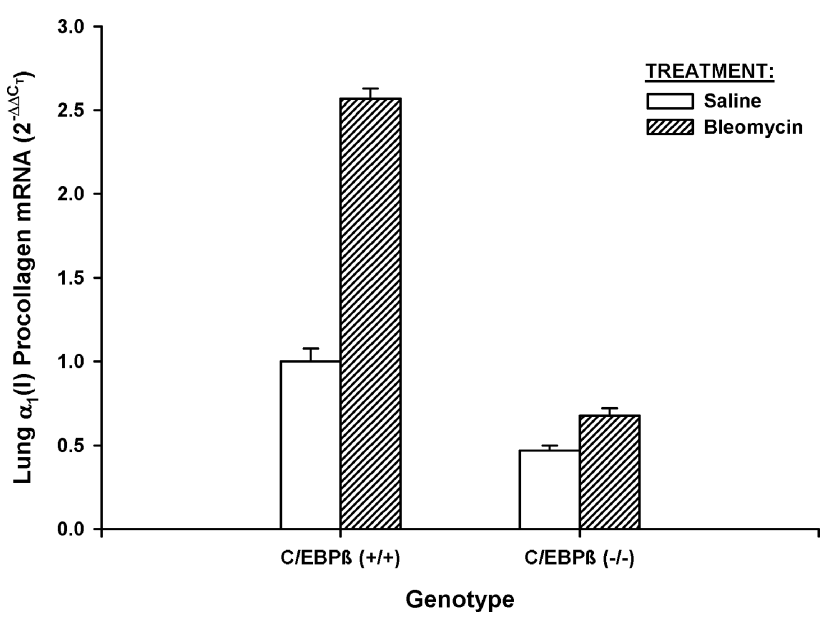

Figure 5. Effects of bleomycin or saline treatment on lung type I collagen mRNA. C/EBP $\beta$ null mice $\left(C / E B P^{-/-}\right)$and its wild-type littermates $\left(C / E B P^{+/+}\right)$were treated with bleomycin or saline, respectively. Seven days after treatment, total RNA was extracted from the lung tissue and $\alpha \mathrm{I}(\mathrm{I})$ procollagen mRNA was detected by real time PCR. Results were expressed as $2^{-\Delta \Delta C T}$, with GAPDH used as the endogenous control and the level in saline-treated wild-type mice used as reference. Data are shown as mean \pm SE from triplicate samples
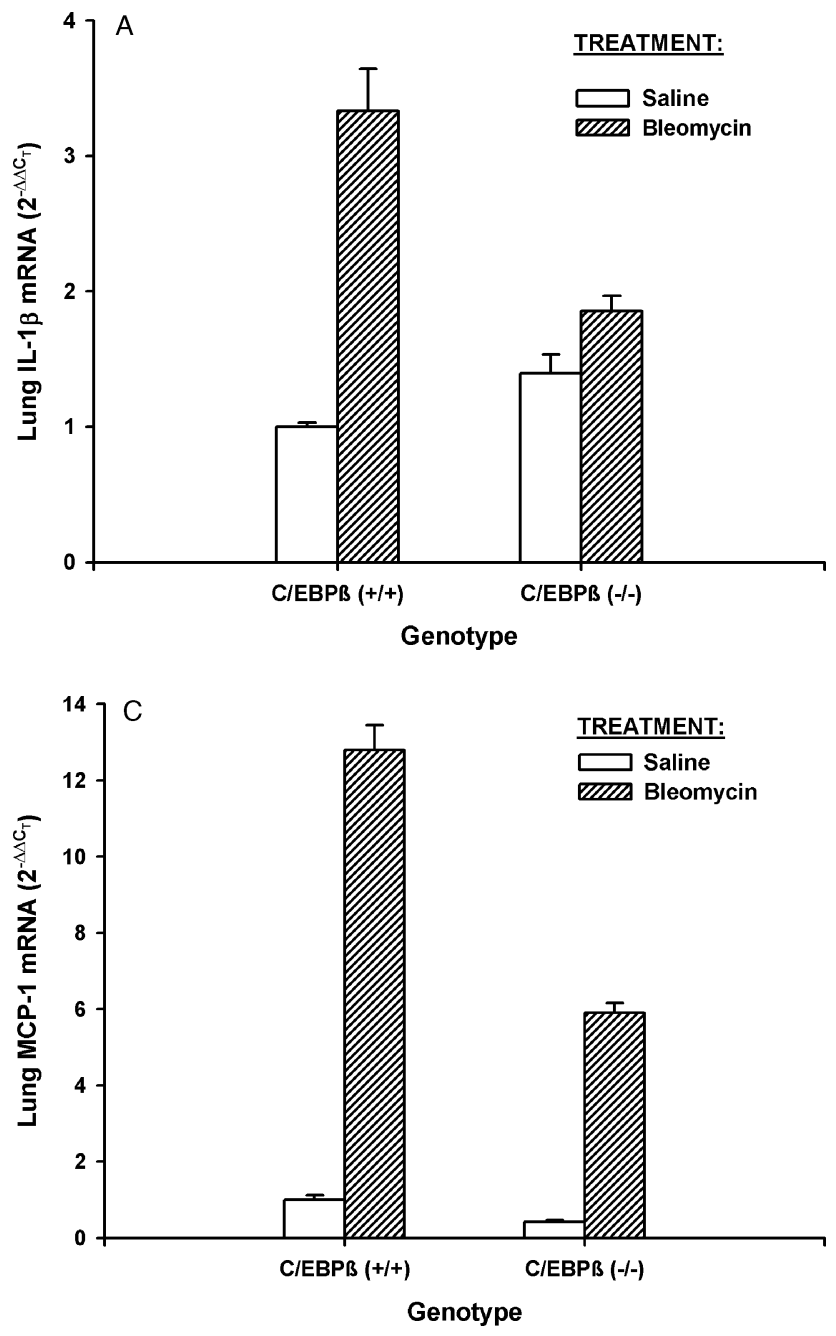

\section{Effects on lung cytokine expression}

Lung cytokine expression is altered in pulmonary fibrosis, and some cytokines, such as TGF $\beta 1$, IL- $1 \beta$, $\mathrm{TNF} \alpha$, and MCP-1, are found to be essential for pathogenesis in animal model studies [16-18]. To determine how $\mathrm{C} / \mathrm{EBP} \beta$ affects pulmonary fibrosis, assessment of cytokine expression in lungs of wild-type and $\mathrm{C} / \mathrm{EBP} \beta$ deficient mice was conducted by real time semi-quantitative PCR analysis. The results showed significantly blunted mRNA levels in the mutant mice (Figure 6A-D). Basal (in saline-treated controls) levels were not significantly different between mutant and wild-type lungs for IL- $1 \beta$ and TNF $\alpha$ mRNAs, but were significantly reduced for MCP- 1 and $\mathrm{TGF} \beta$. However, bleomycin-induced levels in mutant mice were significantly reduced for all cytokine mRNA levels examined relative to those in wild-type controls, except for MCP-1, which despite its lower basal level was almost equally induced by bleomycin (both showed approximately a 12 -fold increase in response to bleomycin treatment). Thus regulation of cytokine
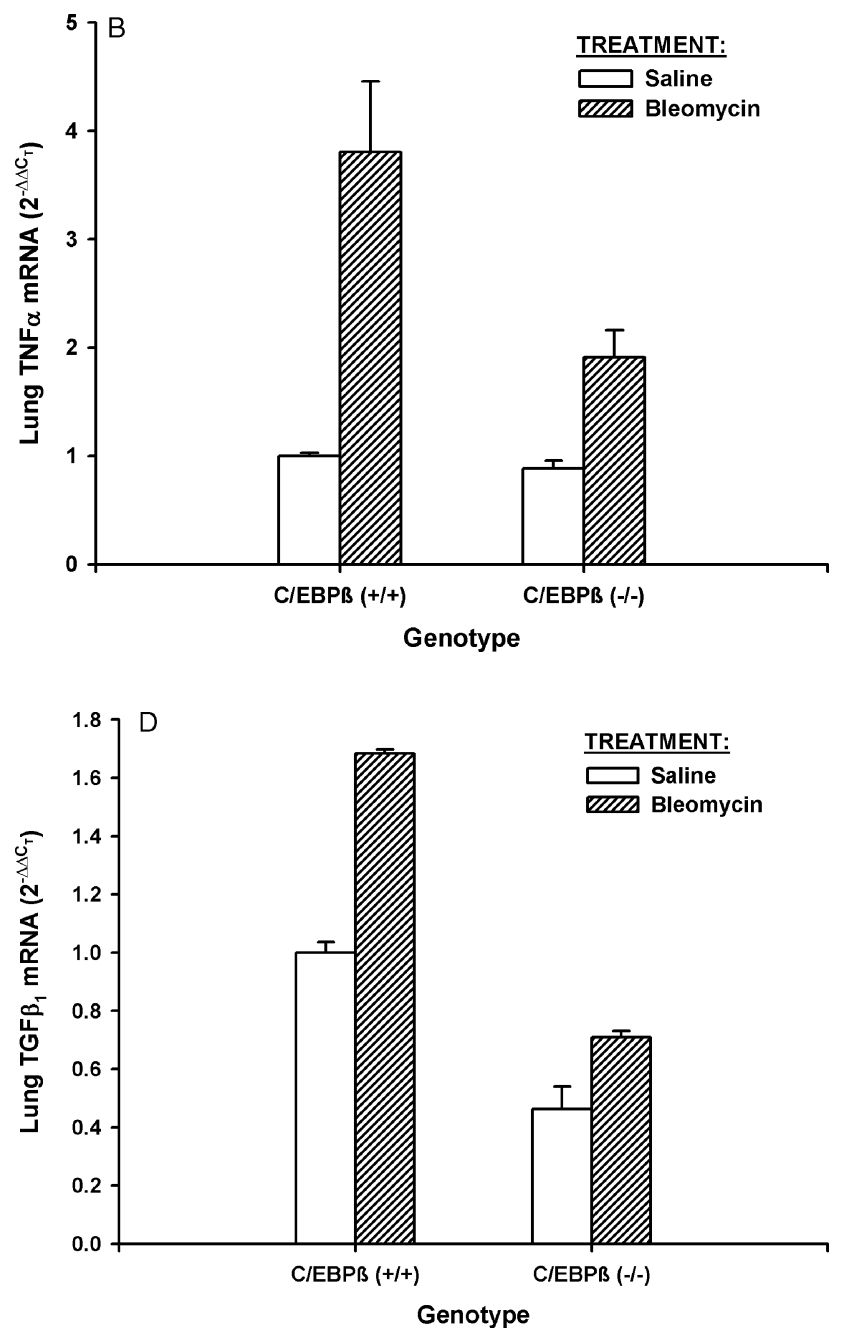

Figure 6. Effects of bleomycin or saline treatment on lung cytokine expression. Total RNA extracted from either bleomycin or saline-treated C/EBP $\beta$ null $\left(C / E B P^{-/-}\right)$and wild-type mice $\left(C / E B P^{+/+}\right)$was analysed for IL-I $\beta(\mathrm{A})$; TNF $\alpha(\mathrm{B})$; MCP-I (C); and $\operatorname{TGF} \beta$ I (D) mRNA by real time PCR. The results were expressed as $2^{-\Delta \Delta C T}$, with GAPDH used as the endogenous control and the values from the respective wild-type saline-treated controls were used as reference. Data are shown as the mean \pm SE from triplicate samples 
expression by $\mathrm{C} / \mathrm{EBP} \beta$ could partially account for the reduced fibrosis in $C / E B P \beta$ null mice relative to that in wild-type mice upon bleomycin treatment.

\section{Effects on myofibroblast differentiation}

De novo genesis of myofibroblasts in fibrosis is readily detectable by assessment of $\alpha$-SMA expression $[1,2,5,6]$. In view of the important roles of the myofibroblast in pulmonary fibrosis [1-4], deficiency in its genesis would result in impaired fibrosis. To evaluate if this might be a contributory factor to the deficient fibrosis seen in $\mathrm{C} / \mathrm{EBP} \beta$ deficient mice, the expression of $\alpha$-SMA in isolated lung fibroblasts was examined in saline or bleomycin-treated wild-type and mutant mice. Analysis of $\alpha$-SMA by western blotting revealed comparable levels of expression in cells isolated from saline-treated wild-type and mutant mice (Figure 7A). However, while cells from bleomycin-treated wildtype mice had higher levels of $\alpha$-SMA expression than those from their corresponding saline-treated controls, the cells from mutant mice were essentially unaffected by in vivo bleomycin treatment. This would suggest defective myofibroblast differentiation in cells from C/EBP $\beta$ deficient mice. Confirmation for such a defect was obtained by real time PCR analysis for $\alpha$-SMA mRNA levels. Analysis using this approach showed an approximately $50 \%$ reduction in basal $\alpha$-SMA mRNA levels in mutant mice compared to wild-type control mice (Figure 7B). This reduced basal mRNA level was minimally altered $(<40 \%$ increase $)$ in cells isolated from bleomycin-treated mutant mice, in contrast to the $>2.5$-fold stimulation (or $>150 \%$ increase) noted in cells from bleomycin-treated wild-type mice. Analysis of the $\alpha-S M A$ gene expression in the lung tissue of $C / E B P \beta$ null mice and their wild-type littermates showed the same trend (data not shown). Thus C/EBP $\beta$ deficiency caused defective genesis of myofibroblasts in bleomycin-induced pulmonary fibrosis.

\section{Effects on fibroblast proliferation}

$\mathrm{C} / \mathrm{EBP} \beta$ is known to be a regulator of cell cycle as well as differentiation [19-22]. Thus, we examined the effect of $\mathrm{C} / \mathrm{EBP} \beta$ deficiency on lung fibroblast proliferation since one of the important phenomena related to pulmonary fibrosis is the increased cell number of fibroblasts in the lung, and the cell proliferation rate has an important effect on the numbers of fibroblasts. As is indicated, growth curve analysis showed that lung fibroblasts isolated from bleomycintreated $\mathrm{C} / \mathrm{EBP} \beta$ deficient mice were more proliferative than cells from wild-type mice (Figure 8A). Doubling time at the linear phase was almost twice as long in the wild-type cells as in the $\mathrm{C} / \mathrm{EBP} \beta$ deficient cells. Furthermore, thymidine incorporation was also significantly higher in the mutant cells than in the wild-type cells (Figure 8B). This is consistent with the concept that less differentiated cells usually have a higher growth or proliferation rate, or alternatively that differentiated (especially terminally differentiated) cells
$A$

\begin{tabular}{|r|c|c|c|c|}
\hline GENOTYPE: & \multicolumn{2}{|c|}{ C/EBP ${ }^{+/+}$} & \multicolumn{2}{c|}{ C/EBP $\beta^{-/}$} \\
\hline TREATMENT: & Saline & Bleomycin & Saline & Bleomycin \\
\hline$\alpha$-SM Actin & --- & $-\infty$ & --- & --- \\
\hline$\beta$-tubulin & $---\infty$ & --- & --- \\
\hline
\end{tabular}

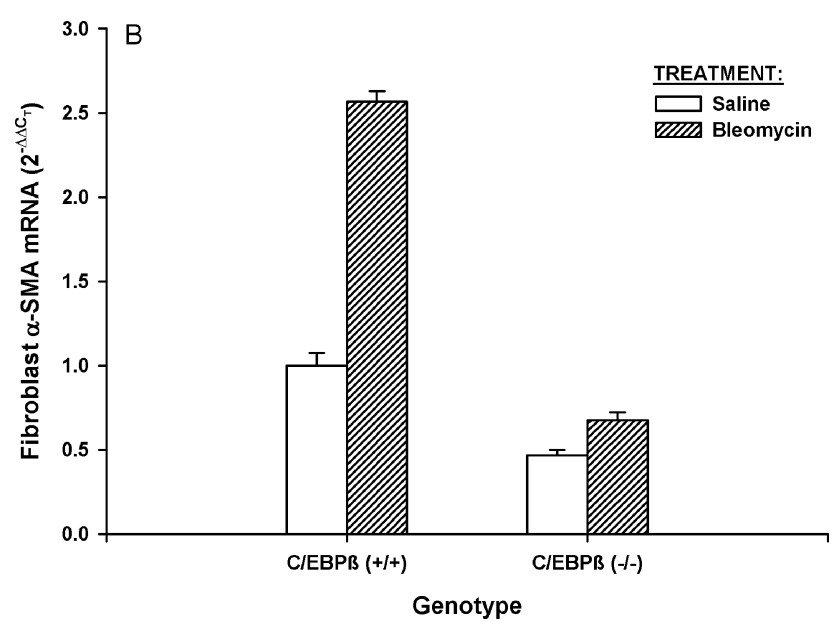

Figure 7. Effects on lung fibroblast $\alpha$-SMA expression. Lung fibroblasts were isolated from either bleomycin-treated or saline-treated $C / E B P \beta$ null mice $\left(C / E B^{-/-}\right)$and wild-type littermates $\left(C / E B P^{+/+}\right)$. (A) Equal amount of total cell lysates were separated in $12 \%$ sodium dodecyl sulphate-polyacrylamide electophoresis gel and blotted against anti- $\alpha$-SMA antibody. To confirm equal loading, the membrane was stripped and reblotted with anti- $\beta$-tubulin antibodies. (B) Equal amounts of total cellular RNA was analysed for $\alpha$-SMA mRNA by real time PCR. Results were expressed as $2^{-\Delta \Delta C T}$, with GAPDH used as the endogenous control and the wild-type saline-treated group used as reference. Data are shown as the mean \pm SE from triplicate samples

have very low proliferative rates, or do not divide at all. Thus one possible explanation is that $C / E B P \beta$ null fibroblasts grew faster because of their failure to differentiate to myofibroblasts.

\section{Discussion}

Two isoforms of C/EBP $\beta$, LAP and LIP, have been described, which are translated from the same mRNA [8-10]. While both share the same $C$-terminal DNA binding domain, LAP has an intact $N$-terminal activation domain that is lacking in LIP [8-10]. Since the binding capability of LIP to the C/EBP $\beta$ binding consensus is four fold higher than that of LAP, the function of LIP is thought to repress the stimulatory effect of LAP on gene expression through competition for binding to the $\mathrm{C} / \mathrm{EBP} \beta$ binding consensus on the target gene promoter [8]. Previously we have shown that LAP activates, while LIP inhibits, $\alpha-S M A$ gene expression [7], which suggests that $\mathrm{C} / \mathrm{EBP} \beta$ may modulate pulmonary fibrosis by regulating myofibroblast differentiation. 

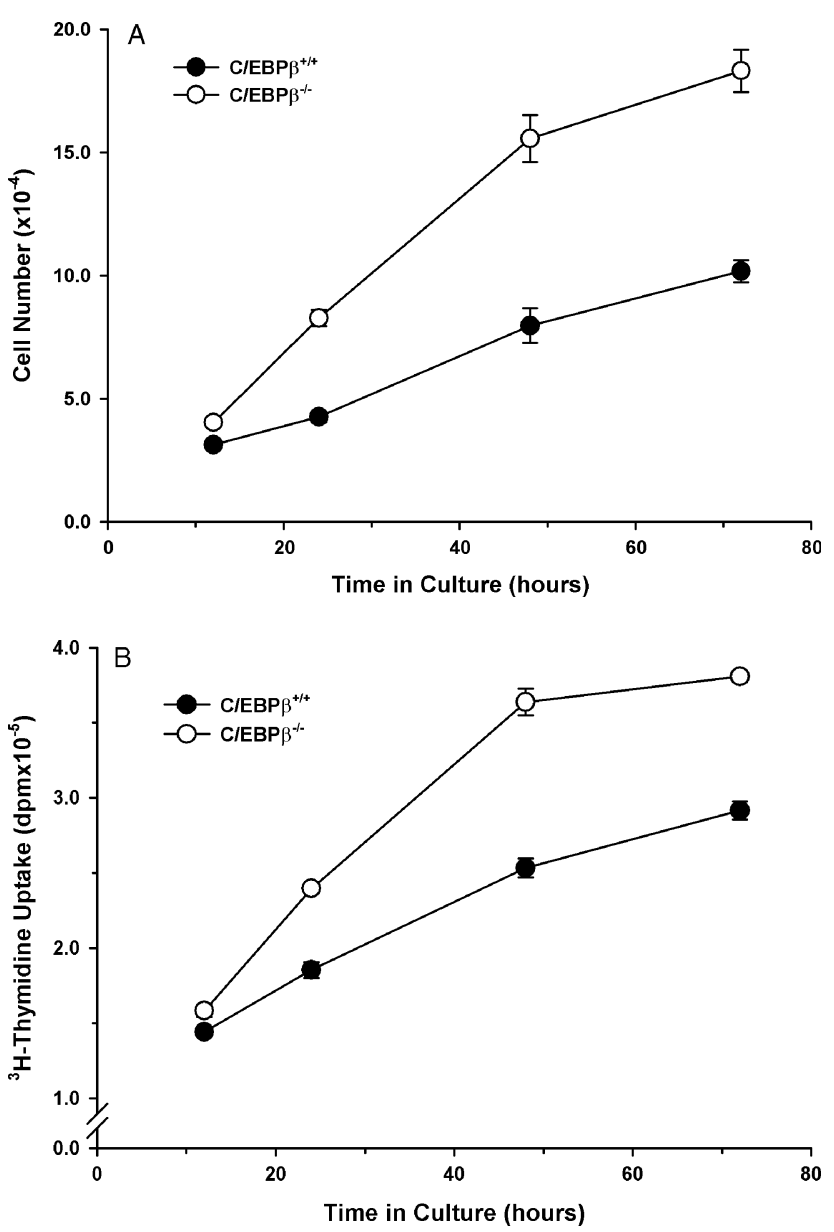

Figure 8. Effects on lung fibroblast proliferation. Mouse lung fibroblasts isolated from either bleomycin-treated $C / E B P \beta$ null mice $\left(C / E P^{-/-}\right)$or wild-type littermates $\left(C / E B P^{+/+}\right)$were counted at the indicated time point in culture $(A)$ or using a scintillation counter for incorporated $\left[{ }^{3} \mathrm{H}\right]$ thymidine (B). The results were shown as mean \pm SE from three independent experiments

In support of such a possibility we first showed that bleomycin treatment significantly increased lung $\mathrm{C} / \mathrm{EBP} \beta$ expression. Furthermore, $\mathrm{C} / \mathrm{EBP} \beta$ deficiency in knockout mice caused significant blunting of fibrosis assessed by both histopathological and biochemical methods. This was accompanied by reduced $\alpha-S M A$ and collagen I gene expression in knockout mice, consistent with reduced myofibroblast differentiation. This is also consistent with previous reports that LAP is an activator for expression of several target genes [7,23]. Since the inhibitory effect of LIP depends on inhibition of the activating effects of LAP [8], reduced fibrosis in $\mathrm{C} / \mathrm{EBP} \beta$ deficient mice was expected. Indeed this was observed as the overall effect of $\mathrm{C} / \mathrm{EBP} \beta$ deficiency in the bleomycin model.

Pulmonary fibrosis is intricately controlled by a variety of cytokines [7,24-26], which are produced by many cell types [26]. Since myofibroblasts are key sources of some of these cytokines [27], including $\operatorname{TGF} \beta 1$ [28], it is conceivable that the reduced myofibroblast differentiation in $\mathrm{C} / \mathrm{EBP} \beta$ deficient mice may contribute to the observed reduction in expression of this cytokine in lungs of deficient mice. However, direct effects of $\mathrm{C} / \mathrm{EBP} \beta$ deficiency on cytokine gene expression cannot be ruled out, and may represent an additional mechanism by which this transcription factor regulates pulmonary fibrosis.

As demonstrated in this paper, defective lung myofibroblast differentiation was found in bleomycintreated $\mathrm{C} / \mathrm{EBP} \beta$ deficient mice, which was accompanied by significantly higher growth rate in lung fibroblasts isolated from these deficient mice. Nevertheless, despite the higher growth rate of $\mathrm{C} / \mathrm{EBP} \beta$ deficient fibroblast in vitro, we did not observe increased fibroblast numbers in $C / E B P \beta$ null mice after bleomycin treatment. Although this is somewhat paradoxical at first glance, the finding is entirely consistent with the notion that the more differentiated myofibroblasts would have a diminished ability to proliferate. This role for $\mathrm{C} / \mathrm{EBP} \beta$ in promoting differentiation whilst inhibiting cell proliferation has been previously observed and may be mediated by GADD45A [29]. Thus despite the potential higher proliferative capacity of the $\mathrm{C} / \mathrm{EBP} \beta$ deficient fibroblasts in vitro, their diminished ability to differentiate to myofibroblasts would have a greater overall inhibitory effect on fibrosis in light of the greater ability of myofibroblasts to elaborate extracellular matrix and cytokines $[3,27,28]$.

Taken together, these findings demonstrate a multifactorial role for $\mathrm{C} / \mathrm{EBP} \beta$ in this model of pulmonary fibrosis. This is partly attributable to the diversity of target genes that are under the control of this complex transcription factor. Thus its deficiency is likely to have a multiplicity of effects. However, given the dismal outlook for treatment of chronic fibrotic diseases, especially using agents that target single molecules, it may be that these multiple effects by a single transcription factor may make it a better therapeutic target. Indeed there is evidence that this might be feasible in the case of C/EBP $\beta$ in studies of how aspirin or salicylates regulate cyclooxygenase-2 expression [30-32]. This approach relies on the importance of phosphorylation of this transcription factor in binding to its binding element, and thus targeting the kinase(s) responsible for this phosphorylation may be a feasible means by which $\mathrm{C} / \mathrm{EBP} \beta$ can be targeted in future studies.

\section{Acknowledgements}

We are grateful for the gift of $C / E B P \beta$ null mice from Dr Peter $F$ Johnson, National Cancer Institute, National Institutes of Health, Bethesda. The excellent technical assistance of Lisa K Riggs and valuable comments from Drs Tianju Liu, Hongfeng $\mathrm{Yu}$ and Myoung Ja Chung are also appreciated.

This work was supported by grants HL28737, HL31963, HL52285, and HL77297 from the National Institute of Health, and an award to SHP from the Sandler Program in Asthma Research. 


\section{References}

1. Gharaee-Kermani M, Phan SH. Molecular mechanisms of and possible treatment strategies for idiopathic pulmonary fibrosis. Curr Pharm Des 2005;11:3943-3971.

2. Phan SH. The myofibroblast in pulmonary fibrosis. Chest 2002;122:286S-289S

3. Zhang K, Rekhter MD, Gordon D, Phan SH. Co-expression of $\alpha$-smooth muscle actin and type I collagen in fibroblast-like cells of rat lungs with bleomycin-induced pulmonary fibrosis: a combined immuno-histochemical and in situ hybridization study. Am J Pathol 1994;145:114-125.

4. Selman M, King TE, Pardo A. Idiopathic pulmonary fibrosis: prevailing and evolving hypotheses about its pathogenesis and implications for therapy. Ann Intern Med 2001;134:136-151.

5. Darby I, Skalli O, Gabbiani G. Alpha-smooth muscle actin is transiently expressed by myofibroblasts during experimental wound healing. Lab Invest 1990;63:21-29.

6. Skalli O, Schurch W, Seemayer T, Lagace R, Montandon D, Pittet $\mathrm{B}$, et al. Myofibroblasts from diverse pathologic settings are heterogeneous in their content of actin isoforms and intermediate filament proteins. Lab Invest 1989;60:275-285.

7. $\mathrm{Hu} \mathrm{B}$, Wu $\mathrm{Z}$, Jin $\mathrm{H}$, Hashimoto $\mathrm{N}$, Liu $\mathrm{T}$, Phan $\mathrm{SH}$. CCAAT/enhancer-binding protein beta isoforms and the regulation of alpha-smooth muscle actin gene expression by IL-1 beta J Immunol 2004;173:4661-4668.

8. Descombes, P, Schibler U. A liver-enriched transcriptional activator protein, LAP, and a transcriptional inhibitory protein, LIP, are translated from the same mRNA. Cell 1991;67:569-579.

9. Ossipow V, Descombes P, Schibler U. CCAAT/enhancer-binding protein mRNA is translated into multiple proteins with different transcription activation potentials. Proc Natl Acad Sci USA 1993;90:8219-8223.

10. Dearth LR, Hutt J, Sattler A, Gigliotti A, DeWille J. Expression and function of CCAAT/enhancer binding proteinbeta (C/EBPbeta) LAP and LIP isoforms in mouse mammary gland, tumors and cultured mammary epithelial cells. J Cell Biochem 2001;82:357-370

11. Liu T, Dhanasekaran SM, Jin H, Hu B, Tomlins SA, Chinnaiyan AM, et al. FIZZ1 stimulation of myofibroblast differentiation. Am J Pathol 2004;164:1315-1326.

12. Hashimoto N, Jin H, Liu T, Chensue SW, Phan SH. Bone marrow-derived progenitor cells in pulmonary fibrosis. $J$ Clin Invest 2004;113:243-252.

13. Gharaee-Kermani M, Hatano K, Nozaki Y, Phan SH. Genderbased differences in bleomycin-induced pulmonary fibrosis. $\mathrm{Am}$ J Pathol 2005;166:1593-1606.

14. Livak KJ, Schmittgen TD. Analysis of relative gene expression data using real-time quantitative PCR and the 2(-Delta Delta C(T)) method. Methods 2001;25:402-408.

15. Sterneck E, Tessarollo L, Johnson PF. An essential role for C/EBPbeta in female reproduction. Genes Dev 1997;11:2153-2162.

16. Chapman HA. Disorders of lung matrix remodeling. J Clin Invest 2004;113:148-157.
17. Gharaee-Kermani M, Phan SH. Role of cytokines and cytokine therapy in wound healing and fibrotic diseases. Curr Pharm Des 2001;7:1083-1103.

18. Kijiyama N, Ueno H, Sugimoto I, Sasaguri Y, Yatera K, Kido M, et al. Intratracheal gene transfer of tissue factor pathway inhibitor attenuates pulmonary fibrosis. Biochem Biophys Res Commun 2006;339:1113-1119.

19. Buck M, Poli V, van der Geer P, Chojkier M, Hunter T. Phosphorylation of rat serine 105 or mouse threonine 217 in C/EBP beta is required for hepatocyte proliferation induced by TGF alpha. Mol Cell 1999;4:1087-1092.

20. Iyer VV, Kadakia TB, McCabe LR, Schwartz RC. CCAAT/ enhancer-binding protein-beta has a role in osteoblast proliferation and differentiation. Exp Cell Res 2004;295:128-137.

21. Martos-Rodriguez A, Santos-Alvarez I, Campo-Ruiz V, Gonzalez S, Garcia-Ruiz JP, Delgado-Baeza E. Expression of CCAAT/enhancer-binding protein-beta (C/EBPbeta) and CHOP in the murine growth plate. Two possible key modulators of chondrocyte differentiation. J Bone Joint Surg Br 2003;85:1190-1195.

22. Sugahara K, Sadohara T, Sugita M, Iyama K, Takiguchi M. Differential expression of CCAAT enhancer binding protein family in rat alveolar epithelial cell proliferation and in acute lung injury. Cell Tissue Res 1999;297:261-270.

23. Attard FA, Wang L, Potter JJ, Rennie-Tankersley L, Mezey E. CCAAT/enhancer binding protein beta mediates the activation of the murine alpha1(I) collagen promoter by acetaldehyde. Arch Biochem Biophys 2000;378:57-64.

24. Hu B, Wu Z, Phan SH. Smad3 mediates transforming growth factor-beta-induced alpha-smooth muscle actin expression. Am $J$ Respir Cell Mol Biol 2003;29:397-404.

25. Song M, He B, Qiu Z. Expressions of TNF alpha, PDGF in alveolar type II epithelial cells of rats with bleomycininduced pulmonary fibrosis. Zhonghua Jie He He $\mathrm{Hu} \mathrm{Xi} \mathrm{Za} \mathrm{Zhi}$ 1998;21:221-223.

26. Hasegawa M, Sato S, Takehara K. Augmented production of chemokines (monocyte chemotactic protein-1 (MCP-1), macrophage inflammatory protein-1alpha (MIP-1alpha) and MIP-1beta) in patients with systemic sclerosis: MCP-1 and MIP-1alpha may be involved in the development of pulmonary fibrosis. Clin Exp Immunol 1999;117:159-165.

27. Zhang K, Phan SH. Cytokines and pulmonary fibrosis. Biol Signals 1996;5:232-239.

28. Zhang K, Flanders KC, Phan SH. Cellular localization of transforming growth factor $\beta$ expression in bleomycin-induced pulmonary fibrosis. Am J Pathol 1995;147:352-361.

29. Guerzoni C, Bardini M, Mariani SA, Ferrari-Amorotti G, Neviani P, Panno ML, et al. Inducible activation of CEBPB, a gene negatively regulated by $\mathrm{BCR} / \mathrm{ABL}$, inhibits proliferation and promotes differentiation of BCR/ABL-expressing cells. Blood 2006; 107:4080-4089.

30. Wu KK. Aspirin and other cyclooxygenase inhibitors: new therapeutic insights. Semin Vasc Med 2003;3:107-112.

31. Wu KK, Liou JY, Cieslik K. Transcriptional control of COX-2 via C/EBPbeta. Arterioscler Thromb Vasc Biol 2005;25:679-685.

32. Wu KK. Control of COX-2 and iNOS gene expressions by aspirin and salicylate. Thromb Res 2003;110:273-276. 